\title{
Foam cell formation associated with a borderline ovarian tumor: a case report
}

Powstawanie komórek piankowatych w przebiegu guza granicznego jajnika: opis przypadku

Department of Obstetrics and Gynecology, Dong-A University, College of Medicine, Busan, Republic of Korea

Correspondence: Jung-Woo Park, MD, PhD, Department of Obstetrics and Gynecology, Dong-A University, College of Medicine, 26, Daesingongwon-ro, Seo-gu, Busan, 49201, Republic of Korea, tel.: +8251240 5090, fax: +8252 244 9553, e-mail: obgypjw@dau.ac.kr

Abstract Foam cell formation is a very common pathologic finding in atherosclerosis, often found in some major organs. However, the involvement of the retroperitoneal organs is very rare and foam cell formation associated with borderline ovarian tumor has not been reported. Borderline ovarian tumors are epithelial ovarian tumors with a low growth rate, low potential to invade or metastasize, and excellent prognosis. Still, a rapidly growing borderline ovarian tumor can exert pressure on the retroperitoneal organs. It may cause retroperitoneal irritation and inflammation, and form a mass lesion in adjacent organs. We report the case of a 41-year-old woman with a borderline ovarian tumor and foam cell infiltration.

Keywords: foam cell, borderline ovarian tumor, retroperitoneum

Powstawanie komórek piankowatych jest powszechnym zjawiskiem patologicznym w przebiegu miażdżycy naczyń krwionośnych, często obserwowanym w niektórych głównych narządach. Jednak do zajęcia narządów zaotrzewnowych dochodzi bardzo rzadko, a w literaturze nie ma doniesień opisujących tworzenie się komórek piankowatych w związku z guzem granicznym jajnika. Guzy graniczne jajnika należą do nowotworów nabłonkowych tego narządu. Odznaczają się niskim tempem wzrostu, niewielką inwazyjnością i zdolnością przerzutowania, a także doskonałym rokowaniem. Jednak szybko rosnący guz graniczny jajnika może uciskać narządy zaotrzewnowe, powodując podrażnienie i stan zapalny w przestrzeni zaotrzewnowej oraz powstanie zmiany o charakterze masy w sąsiednich narządach. W pracy opisujemy przypadek 41-letniej kobiety z granicznym guzem jajnika i naciekiem z komórek piankowatych.

Słowa kluczowe: komórka piankowata, guz graniczny jajnika, przestrzeń zaotrzewnowa 


\section{INTRODUCTION}

$\mathrm{F}$ oam cells are lipid-laden macrophages which are present in all stages of atherosclerosis. Foam cells play a critical role in the occurrence and development of atherosclerosis. The generation of these cells is associated with the imbalance of cholesterol influx and esterification efflux. When the inflow and esterification of cholesterol increase, and the outflow decreases, the macrophages are transferred into lipid-laden foam cells, the protypical cells in the atherosclerotic plaque $^{(1-3)}$. But foam cell formation associated with a borderline ovarian tumor (BOT) has not been reported.

Herein, we report the case of a patient who presented with a foam cell formation associated with a BOT in retroperitoneum.

\section{CASE REPORT}

A 41-year-old nulliparous woman visited the emergency room because of abdominal distention, voiding difficulty, and $3 \mathrm{~kg}$ weight loss over the past three months. She did not have any significant medical or surgical history. On physical examination, there was a large mass in her abdomen. In laboratory tests, the serum cancer antigen (CA) 19-9 level was more than $1,200 \mathrm{U} / \mathrm{mL}$ (normal range, $0-37$ ), and the serum CA-125 level was $219.2 \mathrm{U} / \mathrm{mL}$ (normal range, $0-35$ ). Other laboratory findings were within the normal range. Chest computed tomography (CT) and abdomen-pelvis CT revealed a cystic mass measuring $37.5 \times 33.4 \times 24.2 \mathrm{~cm}$ (Fig. 1).

Under ovarian tumor impression, we performed an exploratory operation. After approximately $18,000 \mathrm{~mL}$ aspiration at the right ovary, a right salpingo-oophorectomy and frozen section biopsy were performed, and the pathological findings confirmed adenocarcinoma. We planned to conduct a staging operation (hysterectomy, left salpingo-oophorectomy, pelvic and paraaortic lymphadenectomy). During

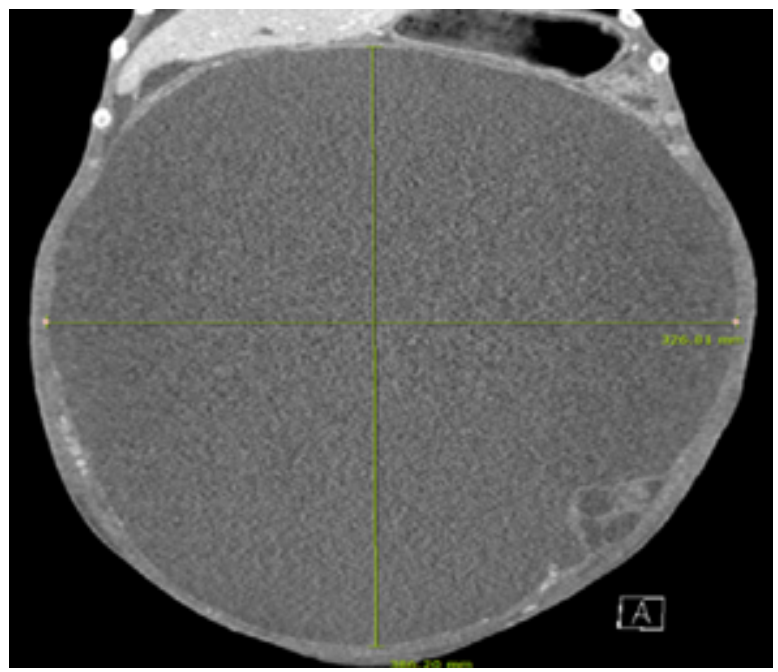

Fig 1. Abdomen-pelvis CT. Large cystic mass with mural mul- the hysterectomy, rice-figured mass lesions suspected of malignancy ranged from the bladder to the right ureter. A frozen section biopsy was performed at the mass, and the result revealed no malignant cells. We consulted with an urologist regarding partial bladder resection.

However, the final pathologic diagnosis revealed a mucinous BOT with stromal microinvasion (Fig. 2A), and the bladder wall and bladder peritoneum showed chronic inflammatory cell infiltrations with foam cells (Fig. 2B). The aspiration fluid contents comprised multiple atypical necrotic cells without tumor cells. The patient was discharged without complications postoperatively. After six months, she is experiencing no abdominal discomfort or voiding difficulty. The follow-up tumor markers were within the normal range, and the abdomen-pelvis CT showed no evidence of recurrence or any remarkable lesions.

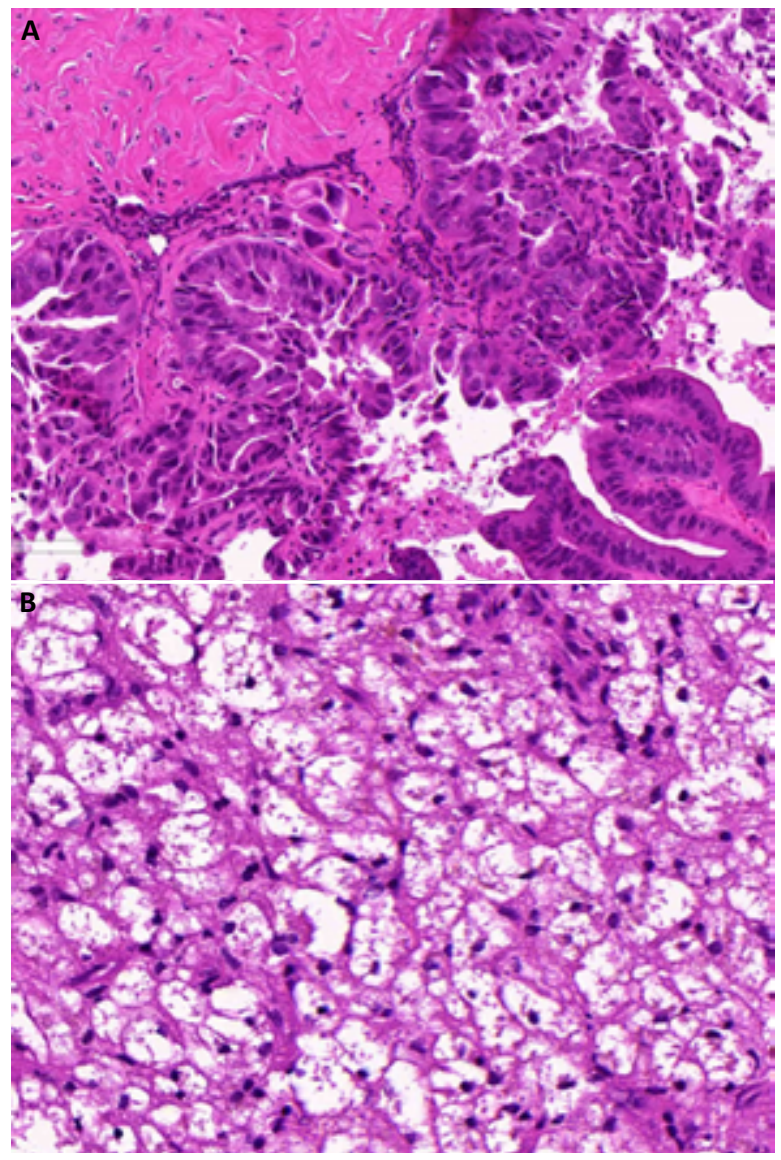

Fig. 2 A. Microscopic findings of the ovarian cyst (A,H\&E, $\times 200)$ and bladder peritoneum $(B, H \nLeftarrow E, \times 200)-$ the cyst chambers were lined by a layer or stratified mucinous cells. In areas, stratification, villous papillae lined by atypical tumor cells were observed, and small foci of stromal invasion. B. Bladder peritoneum clinically suspected metastasis, showed no cancer but the lesion was of chronic inflammation with predominant infiltration of foamy histiocytes and fibrosis. Tissue from the bladder wall shows chronic inflammatory cell infiltration with foam cells and multinucleated giant cells without any cancer cells 


\section{DISCUSSION}

Mucinous BOTs account for approximately $10 \%$ of all primary mucinous ovarian neoplasms. They constitute 30-50\% of BOTs in Western and Middle-Eastern populations, where they are the second most common type of BOT after serous tumors. The converse is true in Asia, where mucinous BOTs account for approximately $70 \%$ of all BOTs ${ }^{(4,5)}$. Mucinous BOTs can occur at any age, but are most likely to develop during the fourth through fifth decades of life $e^{(6)}$. Patients typically present with abdominal distension and/or a pelvic mass. Tumors vary greatly in size, and can measure up to $50 \mathrm{~cm}$ in the largest dimension ${ }^{(7)}$.

The lipid surrounded by macrophages has a "foamy" appearance, so these cells are referred to as foam cells because of their characteristic visual properties ${ }^{(1,8)}$. To the best of our knowledge, this is the first reported case of foam cell formation associated with a BOT.

Low-density lipoprotein and cholesterol homeostasis are maintained by macrophages ${ }^{(2,9)}$. The uncontrolled uptake of oxidized low-density lipoprotein, excessive cholesterol esterification, and impaired cholesterol release result in the accumulation of the cholesterol ester stored as cytoplasmic lipid droplets, and subsequently trigger the formation of foam cells ${ }^{(1)}$. Foam cells are present in all stages of atherosclerosis, a chronic inflammatory disorder in the arterial wall, and participate in inflammatory responses and tissue remodeling ${ }^{(9)}$. Foam cells facilitate the bridging of the innate and adaptive immune response to atherosclerosis, and also accumulate to generate fatty streaks. Foam cells may be detected in some major organs such as the brain, liver, and connective tissue, but are extremely uncommon in retroperitoneal organs ${ }^{(9)}$.

We supposed that a large, rapidly growing BOT might exert pressure on the retroperitoneal organs. It may cause peritoneal cavity irritation wherein continuous chronic inflammatory reactions occur and form a granulated mass lesion in the adjacent organs. When lipid inflammation and congestion occur in the limited retroperitoneal space, it can become a congested mass lesion. As the BOT grows, the infiltrated mass can enlarge continually. The exact pathogenesis has not been clearly explained, and the clinical features are uncertain because of the rarity of the condition. Our patient's foam cell lesion ranged from the bladder to the right ureter. If our surgical treatment has been delayed, the mass lesion might have become large and there would have been severe infiltration in the bladder and ureter.

In the peritoneal cavity, there are many lipid sources such as the omentum, peritoneum, and a limited space for the BOT to enlarge. As the BOT grows, lipid-laden macrophage irritation and inflammation may occur in the limited space, and form an infiltrated lesion on the adjacent retroperitoneal organs.

This is the first reported case of a BOT with characteristics found on the surface shape and balloon-like swelling of the retroperitoneum. This is attributable to the BOT in which the underlying cause is the accumulation of foam cells in the bladder peritoneum

\section{Conflict of interest}

No potential conflict of interest relevant to this article was reported.

\section{References}

1. Hansson GK: Inflammation, atherosclerosis, and coronary artery disease. N Engl J Med 2005; 352: 1685-1695.

2. Bobryshev YV: Dendritic cells in atherosclerosis: current status of the problem and clinical relevance. Eur Heart J 2005; 26: 1700-1704.

3. Williams KJ, Tabas I: Lipoprotein retention-and clues for atheroma regression. Arterioscler Thromb Vasc Biol 2005; 25: $1536-1540$.

4. Khunamornpong S, Settakorn J, Sukpan K et al.: Mucinous tumor of low malignant potential ("borderline" or "atypical proliferative" tumor) of the ovary: a study of 171 cases with the assessment of intraepithelial carcinoma and microinvasion. Int J Gynecol Pathol 2011; 30: 218-230.

5. Song T, Lee YY, Choi CH et al.: Histologic distribution of borderline ovarian tumors worldwide: a systematic review. J Gynecol Oncol 2013; 24: 44-51.

6. Longacre T, Bell D, Malpica A: Tumours of the ovary. In: Kurman RJ, Carcangiu ML, Herrington CS et al. (eds.): WHO Classification of Tumours of the Female Reproductive Organs. IARC Press, Lyon 2014: 26-27.

7. Yemelyanova AV, Vang R, Judson $\mathrm{K}$ et al.: Distinction of primary and metastatic mucinous tumors involving the ovary: analysis of size and laterality data by primary site with reevaluation of an algorithm for tumor classification. Am J Surg Pathol 2008; 32: $128-138$.

8. Stocker R, Keaney JF Jr: Role of oxidative modifications in atherosclerosis. Physiol Rev 2004; 84: 1381-1478.

9. Chistiakov DA, Melnichenko AA, Myasoedova VA et al.: Mechanisms of foam cell formation in atherosclerosis. J Mol Med (Berl) 2017; 95: 1153-1165. 